Review Article

\title{
Environmental Monitoring Around Indian Antarctic Stations
}

\author{
ANOOP KUMAR TIWARI* \\ ESSO-National Centre for Antarctic and Ocean Research, Headland Sada, Vasco da Gama, Goa 403 \\ 804 , India
}

(Received on 17 May 2016; Accepted on 24 November 2016)

\begin{abstract}
Environmental monitoring is integral part of Environmental Impact Assessment (EIA). Continuous efforts of Scientific Committee on Antarctic Research (SCAR), Committee for Environmental Protection (CEP), Council of Managers of National Antarctic Programme (COMNAP) and establishment of Convention for Conservation of Marine Living Resources (CCAMLR) has given impetus to establish scientific approach towards environmental monitoring thus formed a core part of Antarctica Treaty System (ATS).

Adoption of Madrid Protocol in 1998 brought forward guidelines for environmental monitoring and environmental impact assessment defining indicators for assessment of contamination in the environment due to anthropogenic activities. Continuous presence of human and activities in Antarctica no longer justify the meaning of "Sustainable Development" in order to safeguard the pristine nature of continent.

Indian scientists successfully laid the foundation of scientific research in Antarctica during the maiden expedition in 198182. Owing to prevailing requirement, Environmental Monitoring of Maitri station carried out by, the Bhabha Atomic Research Centre, Mumbai (BARC) in air, water, terrestrial and biological environment during austral summer of VIII, IX and X- Indian Antarctic Scientific Expeditions in the year 1988, 1989 and 1990, respectively. Comprehensive environmental monitoring carried out at Maitri station in year 1999, in which air, water, noise, soil and biological indicator selected to form baseline as well as to compare individual indicators, with those assessed in the past from same locations.

Black carbon concentration at site showed the range of carbon concentration as $26.5 \pm 16.2 \mathrm{ng} / \mathrm{m}^{3}$ at Bharati station while average concentration recorded was $13 \pm 5 \mathrm{ng} / \mathrm{m}^{3}$ at Maitri station. $\mathrm{PM}_{2.5}$ values recorded in the range of $1.0-7.0 \mu \mathrm{g} / \mathrm{m}^{3}$, whereas Suspended Particute Matter (SPM) variation recorded in the range of $7.7 \pm 6.0 \mu \mathrm{g} / \mathrm{m}^{3}$ at Maitri station.
\end{abstract}

Keywords: Antarctica; Monitoring; Environmental Impact Assessment; Contamination; Madrid Protocol; Antarctica Treaty; Maitri; Bharati

\section{Introduction}

Antarctica is the last vast wilderness on the planet and it is an important part of Earth's system. By acting as a global heat sink, it helps controlling our climate and weather. Recent development in Antarctica has changed the concept of the pre-International Geophysical Year (IGY) of 1957-1958 of being insignificant in scientific exploration and thereafter represented a major turning point for research in Antarctica. IGY provided a sound foundation for the development of Antarctic scientific activity in a wide range of disciplines, including glaciology, atmospheric sciences and medicine (Gerson, 1958; Walton and Morris, 1990).

Human presence in Antarctica started way back in year 1900, which slowly picked up as other countries started taking interest noticing unique place for conducting science, observing source of probable minerals and hydrocarbons (Blanchette et al., 2004). Apart from scientific interest, commercial and tourism activities also started flourishing in Antarctica since last few decades. More recently, the International Polar Year (IPY) has generated platform for scientific and public interest in the 'white continent', and

*Author for Correspondence: E-mail: anooptiwari@ncaor.gov.in 
inevitably given further impetus to human activity in and around the continent (Tin et al., 2009). As interest grown it also added logistics in many folds to support the all kind of interests. Though in year 1959, while Antarctica Treaty had been signed and Antarctica remained the place for science and peaceful purpose while claims and exploration activities were frozen, yet other activities continues. Antarctic Treaty, signed on $1^{\text {st }}$ of December 1959 by twelve nations and entered into force on $23^{\text {rd }}$ June 1961, establishes the legal framework for the management of Antarctica. At present there are 57 treaty member nations including India in which 29 nations have consultative status and a few more countries are in the process to join for consultative status.

Environmental Protocol, which is also known as "Madrid Protocol" was adopted in 1991 in response to proposals that the wide range of provisions relating to protection of the Antarctic environment should be harmonized in a comprehensive and legally binding form. Article 8 of the Protocol introduces the term Environmental Impact Assessment (EIA) and provides three categories of environmental impacts (less than, equal to and more than minor or transitory), according to their significance. The Article also requires that assessment of planned activities to be undertaken in Antarctica, subject to the procedures set out in Annex I. It draws on and updates the agreed Measures as well as subsequent Treaty meeting recommendations relating to protection of the environment, as part of the Antarctic Treaty System (ATS). It provides for comprehensive protection of the Antarctic environment and dependent and associated ecosystems (ATS, 2002). Article 6 of Protocol emphasize on Co-operation and states; "Each Party undertakes, to the extent possible, to share information that may be helpful to other Parties in planning and conducting their activities in the Antarctic Treaty Area, with a view to the protection of the Antarctic environment and dependent and associated ecosystems".

Madrid Protocol has been underpinned with six annexes which have to be followed and abide by all treaty parties; (a) Annex I - Environmental Impact Assessment, (b) Annex II - Conservation of Antarctic fauna and flora (c) Annex III - Waste disposal and waste management (d) Annex IV - Prevention of marine pollution (e) Annex V - Area protection and management and (f) Annex VI - Liability arising from environmental emergencies. Until 1980-1990, the waste at most Antarctic stations was simply dumped in conveniently located landfill sites close to the station, or alternatively, disposed into the sea or burnt in the open air. The Protocol provided strict guidelines for environmental management and protection, and established the obligation to clean-up abandoned work sites. Adoption of Madrid Protocol in 1998, brought forward guidelines for environmental monitoring and EIA, defining indicators for assessment of contamination in the environment due to anthropogenic activities (Bargagli, 2008; Budhavant et al., 2015; Clarke and Harris, 2003; Clarke, 1988).

In accordance with the recommendation XV-5 of the Fifteenth Antarctic Treaty Consultative meeting, held in Paris in 1989, there are a series of activities that should be monitored. Through continuous monitoring the environmental change can be observed which would setup valuable benchmark to evaluate the state of Antarctic environment. According to the Protocol on Environmental Protection (article 8 and annex I), EIA procedure has been developed for activities undertaken in the Antarctic (Harris and Meadows, 1992; Lyons et al., 1999; Pineschi, 2001).

Environmental monitoring is integral part of EIA therefore continuous efforts of Scientific Committee on Antarctic Research (SCAR), Committee for Environmental Protection (CEP), Council of Managers of National Antarctic Programme (COMNAP) and establishment of Convention for Conservation of Marine Living Resources (CCAMLR) has given impetus to establish scientific approach towards environmental monitoring thus formed a core part of ATS. This paper represents the environmental monitoring and post-EIA conducted after establishment of Indian permanent stations "Maitri" and "Bharati" in Antarctica.

\section{Indian Antarctic Stations - Area of Study}

Realizing the importance of Antarctica in terms of Scientific knowledge, first winter-over station, "Dakshin Gangotri”" was established in year 1983 on ice-shelf of Princess Astrid coast $\left(70^{\circ} 05^{\prime} 37^{\prime \prime} \mathrm{S}\right.$ Latitude, $12^{0} 0$ ' $00^{\prime \prime}$ E Longitude). Then it got abandoned in year 1989, as it started sinking in snow due to internal heat stress and snow accumulation in periphery of station. Second permanent Indian station 
was established on rock terrain of Schirmacher Hills in east Antarctica, in year 1988-89, on the nunatak Vassfjellet close to the ice shelf, about $80 \mathrm{~km}$ from the ice shelf edge (Fig. 1). Maitri is situated in an area of base rock and surrounded by a number of small lakes. A glacier to the south of station covers parts of the nunatak and ends about 400 meters from the main building. Maitri station can accommodate 25 persons inside main building and approximate 50 persons in summer huts, located nearby main structure.

Bharati station is also all year round station which became functional in year 2012, located in Larsemann hills area at Grovnes on the rocky terrain in east Antarctica, nearly $2500 \mathrm{~km}$ away from Maitri station (Fig. 2). Bharati station can accommodate 15 persons during winter and 35 persons during summer period. Bharati station is located very close to sea, nearly 300 meters away from the edge of sea-peninsula conjunction.

The scientific investigations being carried out since first expedition includes but not limited to, studies on meteorology, geomagnetism, environmental science, radio-wave propagation, geology, glaciology,

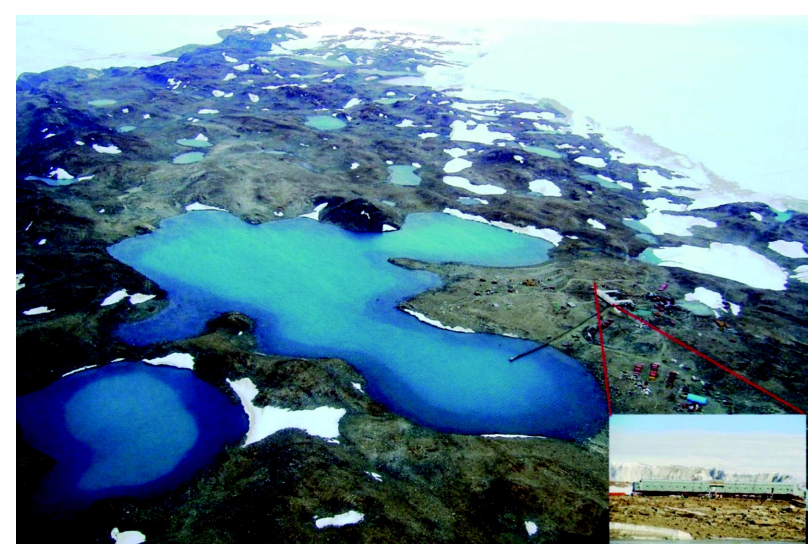

Fig. 1: Maitri Station in Schirmacher Hills, East Antarctica

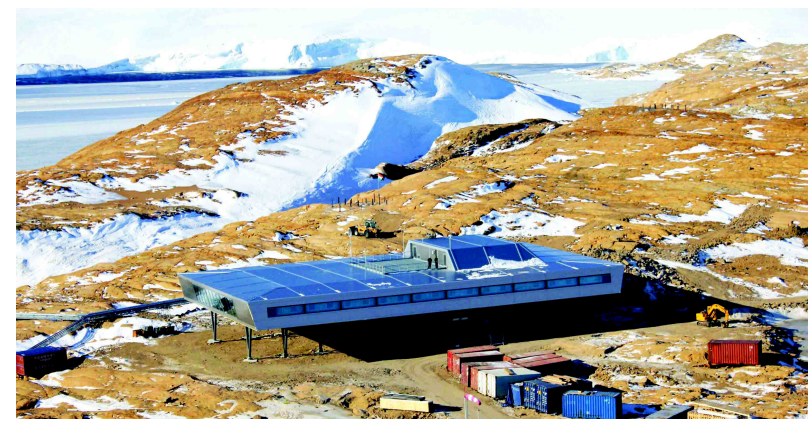

Fig. 2: Bharati Station in Larsemann Hills, East Antarctica chemistry, physical sciences and microbiology of the Antarctic ice and the study of freshwater lakes. Since then scientific studies were carried out in various disciplines and valuable results are extracted which have proven to understand a lot about icy continent.

\section{Environmental Monitoring}

Need for environmental monitoring arises while Parker and Vince Howard (1977) carried out first environmental impact monitoring of drilling project in Antarctica referring the procedure developed by Leopold et al. (1971). Kennicutt Ii (1990), also brought forward the need of monitoring and conservation of oil spill to protect the pristine Antarctic Environment. Signing of Madrid Protocol in year 1991 by the treaty parties further emphasized environmental monitoring due to human impact in collaborative manner to highlight the urgent need for decision makers (Walton and Morris, 1990; Walton and Shears, 1994).

\section{Environmental Monitoring of Indian Stations in Time Scale}

Environmental monitoring of Indian stations, Dakshin Gangotri and Maitri had been conducted by the Bhabha Atomic Research Centre (BARC, Mumbai) in 1988, 1989 and 1990. During year 1994, 1995, 1996, 1999 and 2000, environmental monitoring had been carried out by National Environmental Engineering Research Institute (NEERI, Nagpur). Veermata Jijabai Technological Institute (VJTI) undertook environmental monitoring in the year 2002 around Maitri station. Baseline monitoring information during year 2007, 2008, 2009 and 2010 for the new Indian research station (Bharati) as well as Maitri has been collected by Shriram Institute of Industrial Research (SIIR, New Delhi). ESSO-National Centre for Antarctic and Ocean Research (NCAOR, Goa) entrusted with EIA and environmental monitoring starting from year 2003, 2006 and 2012 to 2015-16, for Maitri and Bharati stations.

\section{Environmental Indicators}

CEP and COMANP developed guideline to choose parameters of relevance which are presented in Table 1. These indicators are subjective and should be selected based on the geography, activities undertaken, likely impact on environment including short-term and long-term assessment, future activities 
Table 1: An overview of some potential indicators and parameters for use in monitoring programmes in Antarctica

\begin{tabular}{ll}
\hline Indicator & Parameter \\
\hline "Footprint" & $\begin{array}{l}\text { Area subject to human activity, e.g. spatial coverage of buildings and associated impact } \\
\text { including roads, pipes etc; number and location of field expeditions }\end{array}$ \\
Air quality & $\mathrm{SO}_{2}$, particulates \\
Soil quality & Erosion (e.g. footpaths), metals, TPH, PAH \\
Sea water quality & TSS, DO, BOD, COD, pH, conductivity \\
Fresh water quality & TSS, DO, BOD, COD, pH, conductivity \\
Snow and ice quality & Metals, TPH, particulates \\
Vegetation quality & Spatial extent, metals \\
Wildlife health & Population size, breeding success \\
Fuel handling & Amount consumed, number of spills, size and location of spills \\
Aircraft/vehicle operations & Distance travelled, number of landings, fuel consumed \\
Solid and liquid waste & Waste types (including hazard), volume/weight \\
Waste water & TSS, DO, BOD, COD, pH, conductivity, faecal coliforms, volume \\
Field activities & Number of person days in field, location of field camps \\
Introduced organisms & Species, distribution, population size \\
EIA/permit compliance & Number of breaches recorded \\
\hline
\end{tabular}

as well as wilderness values (COMNAP, 2005). Since, in Antarctica unified emission standards are yet to be developed and implemented, best practice and stringent standards may be adopted. To achieve results in practical sense, state-of-the-art instrument and equipment may be implied to record and monitor observations and should be calibrated according to standard protocol.

Environmental study, under Indian Antarctic Programme carried out since first expedition in year 1981-82 when hydro-chemical studies of polynya in Antarctica and fresh water lakes conducted by CSIRNational Institute of Oceanography (NIO) Goa. Environmental Monitoring of Maitri station started before the Protocol put on force in year 1998. Owing to prevailing requirement, environmental monitoring of Maitri station carried out by BARC, for air, water, terrestrial and biological environment during austral summer of VIII, IX and X-Indian Antarctic Scientific Expedition (ISEA) in the year 1988, 1989 and 1990, respectively. BARC, collected background baseline data on natural radioactivity and trace heavy metal concentrations in air, water and rock samples and also measured background gama dose rate in air and tritium levels in the ocean as well as in Antarctic fresh water Lakes around Maitri station (Ramachandran and
Balani, 1998; Sathe, 1994).

During XIII to XVI-ISEA (austral summer of 1993-95), environmental monitoring programme undertaken by, NEERI, an organisation under Council of Scientific and Industrial Research (CSIR), Government of India, organization. Observations carried out selecting relevant and important environmental indicators, i.e., Suspended Particulate Matter (SPM) Sulfur dioxide $\left(\mathrm{SO}_{2}\right)$ and Oxides of Nitrogen (NOx). Simultaneously samples were collected of water, wastewater, and soil and then analyzed for various physicochemical (i.e. $\mathrm{pH}$, temperature, conductivity, turbidity, alkalinity, total hardness, chloride, sulphate, sodium, potassium, nitrate, nitrite, ammonical nitrogen, total phosphate, dissolved oxygen (DO), biochemical oxygen demand (BOD), chemical oxygen demand (COD), oil and grease, hydrocarbon and heavy metals like cadmium, copper, chromium, lead, iron and zinc) as well as for biological parameters. Emission from the stacks of boilers, incinerators and exhaust of vehicles were also monitored (Ghosh et al., 1997a; Ghosh and Ramteke 1997; Ghosh et al., 1997b). Referring to guidelines, comprehensive environmental monitoring carried out at Maitri station in year 1999-2000, in which air, water, noise, soil and biological indicator selected to form 
baseline as well as to compare individual indicators, with those assessed in the past from same location (Tiwari et al., 2006).

\section{Air Environment}

Use of fossil fuel in Antarctica is required for survival, as modern material are also required to sustain in adverse climatic condition, however use of fuel and material, generates emission and waste. Estimation and measurement of aerosol particles are important to understand effect on climate variability as well impact on the human health. It also becomes imperative to classify particles into natural and anthropogenic source and origin (Anonymous, 1981; Buettner, 1962; Kondratyev et al., 1986). Kallenborn et al. (2015), also agree that, long term monitoring data are useful for in-depth interdisciplinary research on contaminant pattern profiles, spatial and temporal trend studies, environmental fate and distribution modeling, and understanding of regional transport pathways in the future.

SPM in air is usually very irregular in shape. While liquid particles present in mists and sprays tend to be spherical, the solid particles making up most dust and fumes fall into one of the three general classes: granular, flaky and needlelike. $\mathrm{PM}_{2.5}$ collected during December 2014-March 2015 at Maitri station at upwind and downwind direction analyzed to observe the variation. The upwind concentration has mean value of $2 \pm 1.8 \mu \mathrm{g} / \mathrm{m}^{3}$. The downwind concentration ranges from a minimum of $1 \mu \mathrm{g} / \mathrm{m}^{3}$ to $7 \mu \mathrm{g} / \mathrm{m}^{3}$ with the mean value of $3 \pm 2.2 \mu \mathrm{g} / \mathrm{m}^{3}$ (Fig. $3)$. This increase in the concentration can be attributed

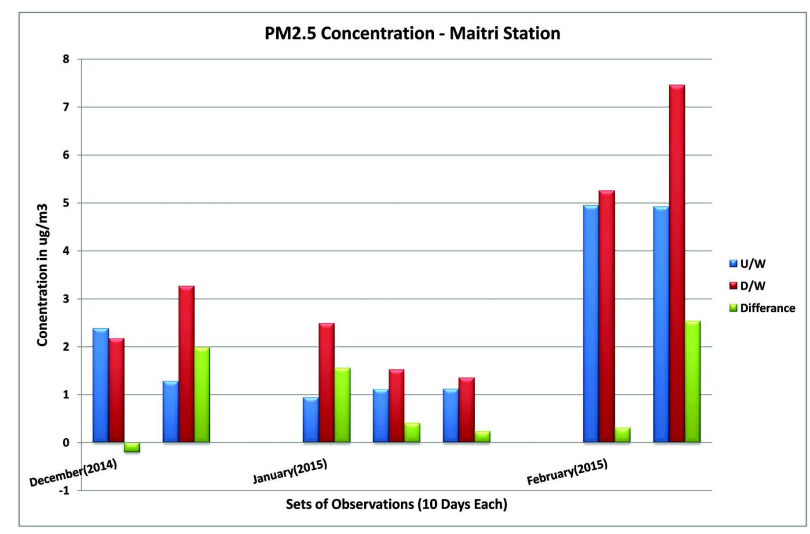

Fig. 3 : $\mathrm{PM}_{2.5}$ Concentration Showing results of Upwind and Downwind of Maitri Station to the local activities carried out near the station (Pande, 2015). Ghosh and Ramteke (1997) reported oxygen content in the exhaust of various stacks attached with incinerator, boiler and generator in between $12-14 \%$, whereas $\mathrm{CO}_{2}$, varied from 0.6 to $1.2 \%$ at Maitri station, suggested need of tuning of machineries being operated in station.

Ambient air quality at the site in Larsemann Hills before setting up station Bharati carried out for Respirable Particulate Suspended Matter (RSPM), $\mathrm{SO}_{2}$, NOx and Carbon monoxide (CO), during austral summer for three consecutive years (2007-2010) by SIIR. Concentration values shows RSPM varied from 11 to $37 \%$. However, increase in concentrations of SPM and RSPM were noticed due to site preparation activities. $\mathrm{SO}_{2}$ concentration varied from $<1$ to 3.9 $\mu \mathrm{g} / \mathrm{m}^{3}$, whereas NOx varied form 4.1-7.4 $\mu \mathrm{g} / \mathrm{m}^{3}$ (Khandal et al., 2010; Ravindra et al., 2011).

Year round measurement of the NOx, carried out in year 2013-14 at Maitri station. Normal values were recorded in range of $0.14,0.12,0.02 \mathrm{ppb}$ of $\mathrm{NOX}, \mathrm{NO}_{2}$ and $\mathrm{NO}$ respectively. Particular episodes were also recorded 7.2, 6.04 and 1.52 ppb against the normal values during winter period while concentration recorded for few hours in many folds of normal occurrence of NOx (Fig. 4). It may be the chemical processes taking place in the upper atmospheric region is coupled to the lower atmospheric region and modifies the weather parameters as well the electric environment and thus the monitoring of the atmospheric electric parameters can be a tool to understand the coupling processes between the space weather events and the meteorological weather events. The mechanism behind those observations may be production of NOx in the upper atmospheric region, due to the particle precipitations or the transportation of Lightning NOx (LNOx) from the tropic and sub tropic region to the polar region through the general global circulation and descending from the upper atmosphere (Environmental Monitoring of Indian Antarctic Stations, unpublished observations by A K Tiwari).

Aerosol Black Carbon (BC) is a unique tracer for combustion emissions: it has no non-combustion source. It is inert and long-lived in the atmosphere, and can be transported over great distances. Average concentration of black carbon at Maitri station, due 
Hourly Average Concentration of $\mathrm{NO}, \mathrm{NO}_{2}$ and $\mathrm{NOx}$

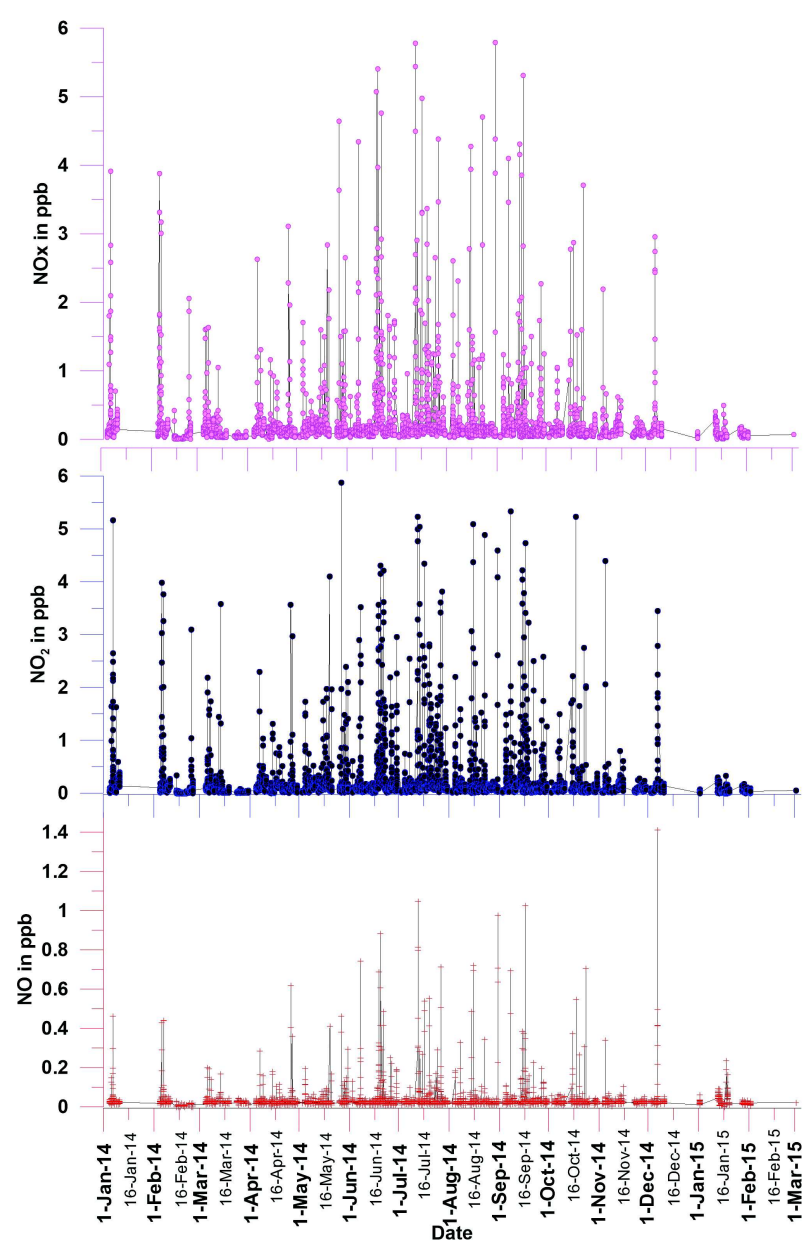

Fig. 4: Year round NOx measurement at Maitri Station in Antarctica

to long range transport, recorded was $13 \pm 5 \mathrm{ng} / \mathrm{m}^{3}$. Aethelometer was operated, at the Grovnes before establishment of Bharati station during XXVII-ISEA to obtain black carbon concentration at site. Results showed the range of carbon concentration as $26.5 \pm 16.2 \mathrm{ng} / \mathrm{m}^{3}$ (Chaubey et al., 2010).

Aethelometer measurements deployed to elucidate the variations of combustion-related aerosol emissions at Maitri station. Black carbon concentrations varied both as a function of wind direction and source strength over the diurnal cycle. Average concentration of black carbon aerosol varies in the range of $10-100 \mathrm{ng} / \mathrm{m}^{3}$, as depicted in continuous measurement at Maitri station since year 2013-14, which includes contribution from local source also. Higher concentrations are recorded due to prolong high wind thus ablation of snowpack which has resulted mixing of deposited back carbon in the air during winter period while vortex formation, acts as barrier for transfer of long range transport of aerosol from other continent (Environmental Monitoring of Indian Antarctic Stations, unpublished observations by A K Tiwari).

Mercury is toxic chemical which introduced into our environment naturally as well as through manmade sources. Human sources may include incinerators, coal burning, certain industrial process, batteries and some electrical items (Witherow and Lyons, 2008). Elemental mercury plays an important role in cycle of mercury in the atmosphere and ocean (Brooks et al., 2008; Cossa et al., 2011). During, austral summer of XXXII and XXXV-ISEA, Total Gaseous Mercury (TGM) measured at Maitri station and found to be in range of $1.0-3.5 \mathrm{ng} / \mathrm{m}^{3}$ in ambient air except the particular episodes while concentration of TGM exceeded $5 \mathrm{ng} / \mathrm{m}^{3}$ during and after occurrence of blizzard (Tiwari and Qureshi, 2016).

\section{Water Environment}

There are more than 105 lakes (epi-shelf, pro-glacier and land-locked) identified in Schirmacher Hills within $35 \mathrm{~km}^{2}$ area. Multi-year assessment (2011-2015) of water quality in term of physico-chemical parameters shows, most of lakes are indicating slight acidic $\mathrm{pH}$ and deprived of minerals, even one or two lakes shown $\mathrm{pH}$ lower than 5. However traces of zinc and iron and other heavy metals have been noticed in ZubLake (Priyadarshini Lake). This is being attributed to occasional seepage of waste water from collection pond and mixing in the stream connected as in-feed to Zub-Lake as well as water circulation though iron pipeline, however other wind-blown as well as leftout metallic articles are seen at the bottom of lake (Unpublished observations by AK Tiwari). The water quality of the lake has not changed by the intrusion of small quantity of wastewater through seepage water channel from possibly due to maintained high dilution ratio as well as augmentation with replenish of water from the glacial melt water of approximate $61000 \mathrm{~m}^{3}$ feeding Zub lake every year, however volume may vary depending upon the ambient temperature of particular year (Tiwari and Nayak, 2007). Conductivity, heavy metals and ionic characteristics (Fig. 5) varies in terms of special and temporal change, however characteristics of lakes 

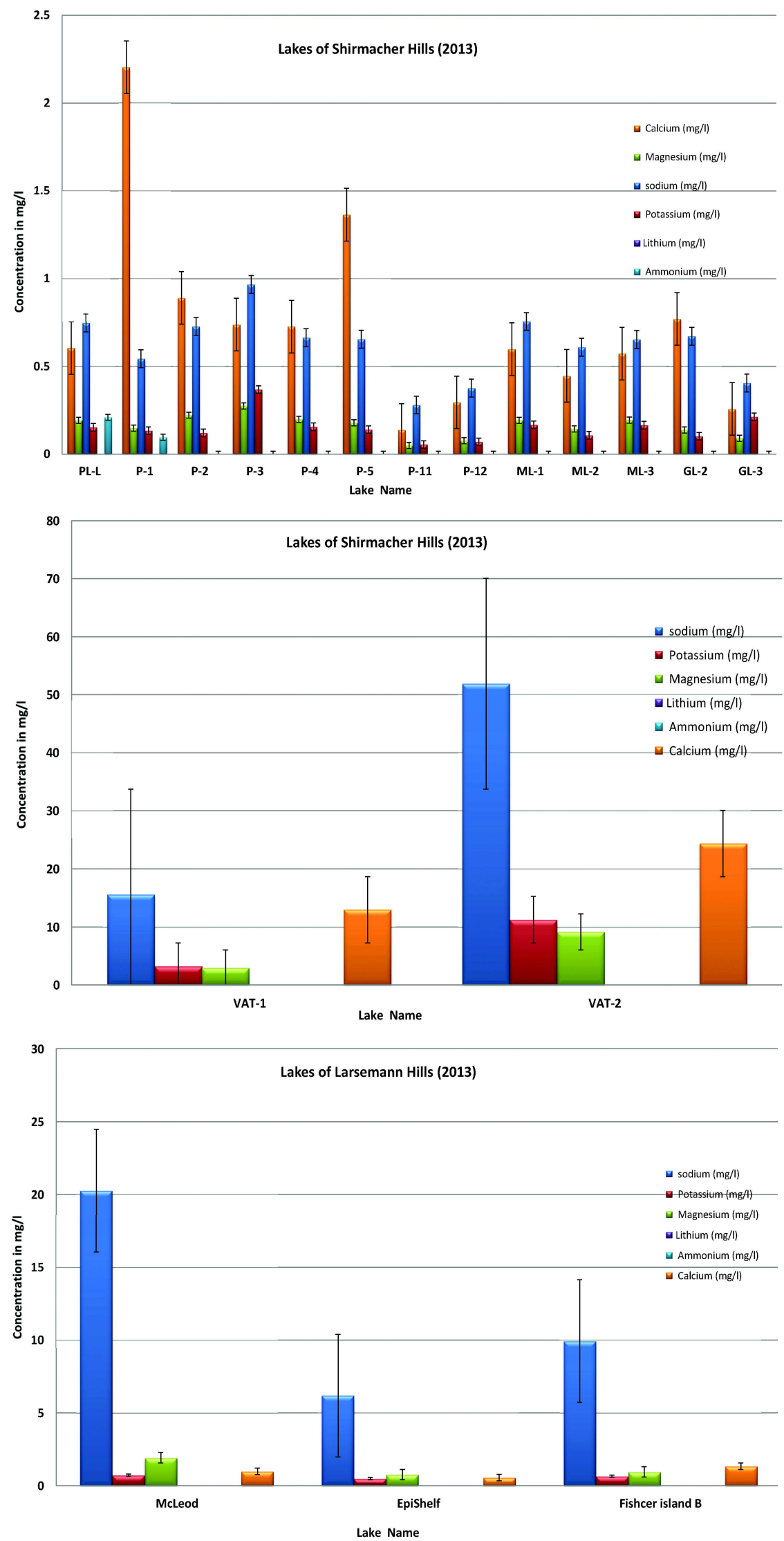

Fig. 5 : Cation Distribution in the Lakes of Shirmacher and Larsemann Hills are still comparable without any significant change with water quality of 38 lakes had been carried out by Kumar $e t$ al. (2002) during XVIII-ISEA, ascertaining various physicochemical parameters.

Water quality monitoring carried out by SIIR, during XXVII to XXIX-ISEA in Grovnes, Stornes and Broknes peninsula. Water quality parameters did not show significant variations. However, some parameters showed marginal inter-annual variations between lakes. For instance, chloride values in all lakes were within the range of freshwater, but in two Lakes results shows $58-836 \mathrm{mg} / \mathrm{l}$ and $351-353 \mathrm{mg} / \mathrm{l}$ the values varied widely and also indicated saline water influence. Most of the metals analysed were showing values from below detectable to very low values. Nutrient parameters such as $\mathrm{PO}_{4}$ and $\mathrm{NO}_{3}$, though varied marginally between lakes, showed lower values, suggesting that the lake in Larsemann Hills are not subjected to organic or inorganic pollution (Khandal et al., 2010; Ravindra et al., 2011).

\section{Waste Water Treatment}

The Rotating Biological Contactor (RBC) are a range of complete self-contained sewage treatment plants which are designed for small communities and manufactured in different range of sizes (Connor, 2008). These units are ideal for single house, small housing 
developments, hotels, public houses and small commercial developments. The units are compact, self-contained, single-piece treatment plants that utilize natural biological processes to effectively break down domestic and commercial waste water (Hiras et al., 2004). RBC is most preferred biological treatment system in Antarctica to treat grey water generated from the station. Two RBC were installed at Maitri station in year 1989-90 to treat the grey water generated from kitchen, laundry and bathrooms. Efficacy assessment also has been carried out during various expeditions, considering appropriate indicators. The performance of RBC is evaluated in terms of BOD, COD and Ammonia nitrogen $\left(\mathrm{NH}_{3}-\right.$ N). During year 2011-12, efforts were made to improve the efficacy of RBC to tune it to meet design parameters. Performance evaluation of RBC was carried out to assess the treatment efficiency of biodiscs. It was noticed that the treatment efficiency of B3- RBC was $27.8 \%$ in terms of BOD and $41.3 \%$ in terms of COD. Whereas, B1-RBC was working with efficiency of $66.7 \%$ in terms of BOD and $68.9 \%$ in terms of COD (Tiwari et al., 2009). A laboratory experiment of tertiary treatment of wastewater is carried out using activated carbon method, which gave the BOD removal up to $84 \%$. Bharati station has been augmented with advance wastewater treatment system comprising Membrane Bio Reactor (MBR). System is functioning and meeting most of the time designed effluent standards, except when over loading of influent observed. Wastewater outfall at Maitri and Bharati station have been analysed for presence of pathogens and results found positive in few samples, presented in Table 2 (personnel communication, unpublished data by S Kerkar).

\section{Noise Environment}

Numerous study conducted worldwide shows that increased noise due to machinery or aircraft/helicopter impart health impact as well as annoyance. Noise barrier and Personal Protective Equipment should be used at high noise level area (Babisch et al., 2009; Baldauf et al., 2008). High noise level can lead to sleep deprivation which can affect physical and mental health (Douglas and Murphy, 2016; Murphy et al., 2009). Noise level monitoring conducted in year 201213 around Maitri station shows Leq values varied in range of 48 to $63 \mathrm{dBA}$ (with wind effect), whereas electrical generators produced $108 \mathrm{dBA}$ and helicopter take off generated $103 \mathrm{dBA}$ of noise levels (Unpublished observations by A. K. Tiwari). These results are close to earlier monitored by Ghosh and Ramteke (1997) and Tiwari and Kulkarni (2004) which indicated that in and around Maitri station noise level varied from35-57 dBA, whereas near operation of various machineries it varies in range of 66 to 105 dBA. Antarctica being unique place more appropriate indicators should be developed to limit the exposure time and duration of noise levels,

\section{Biological Environment}

Antarctic lakes possess relatively short and simple food chain, Kok and Grobbelaar (1978) states that the zooplankton occupies the top of the food chain due to the absence of fish. They found a significant correlation between average primary production rates measured by Grobbelaar (1974) and zooplankton biomass in various water bodies, and concluded that zooplankton rely heavily on algal production and play an important role as consumers of primary producers.

Study on phytoplankton at ice edge was carried out by NIO during III-IASE (Sengupta, 1983). Micro fauna of the Priyadarshini Lake of Schirmacher Hills were studied with the objectives; evaluation of environmental characteristics, faunal density and distribution. Bacteria and Yeasts of Antarctica are studied by Centre for Cellular and Molecular Biology (CCMB), Hyderabad, during IV-IASE to investigate the molecular biology of microorganisms with a view to understand the molecular mechanism of adaptation in extreme cold conditions (Alam et al., 2005). Shivaji et al. (1989), were the first to report Planococcus species from the Antarctic habitat. Alam et al. (2003), isolated a new member of the genus Planococcus, from a cyano-bacterial mat sample collected in the

Table 2: Heterotrophic and pathogenic counts at Maitri and Bharati station's wastewater outfall

\begin{tabular}{lllllll}
\hline Stations & Nutrient Agar & Zobell Marine Agar & Mac Conkey Agar & SS Augur & TCBS Agar & EMB \\
\hline Maitri & $2.31 \times 10^{5} \mathrm{cfu} / \mathrm{mL}$ & $1.98 \times 10^{5} \mathrm{cfu} / \mathrm{mL}$ & $0.45 \times 10^{5} \mathrm{cfu} / \mathrm{mL}$ & $0.75 \times 10^{5} \mathrm{cfu} / \mathrm{mL}$ & $0.35 \times 10^{5} \mathrm{cfu} / \mathrm{mL}$ & $0.49 \times 10^{5} \mathrm{cfu} / \mathrm{mL}$ \\
Bharati & $4.31 \times 10^{6} \mathrm{cfu} / \mathrm{mL}$ & $3.86 \times 10^{6} \mathrm{cfu} / \mathrm{mL}$ & $0.3 \times 10^{6} \mathrm{cfu} / \mathrm{mL}$ & $0.8 \times 10^{6} \mathrm{cfu} / \mathrm{mL}$ & $0.23 \times 10^{6} \mathrm{cfu} / \mathrm{mL}$ & $0.77 \times 10^{6} \mathrm{cfu} / \mathrm{mL}$ \\
\hline
\end{tabular}


vicinity of Maitri, the Indian station, in Schirmacher Hills, Antarctica. Based on phenotypic and genotypic data, they concluded that the new isolate merits separate species status, and therefore, proposed the name Planococcus maitriensis for strain S1.

A profiling underwater radiometer was used in the water around Maitri during thirteen IASE by NIO and it was concluded that greater productivity in the Antarctic waters is due to higher quantum of light received. The bacterial and fungal population of Antarctica atmosphere was monitored and it was found that bacterial population was dominated by Gram positive rods and fungal population by Penicillium species (Lokobharathi and Krishnakumar, 1997). Bryophytes collected in Schirmacher oasis represents, nine species of mosses under five genera and four families. Around 19 Lichen flora of Schirmacher hills is collected and studied by the National Botanical Research Institute (NBRI), Lucknow along with heavy metal analysis of lichen (Bera, 2012). Algal flora diversity study was carried out in fresh water streams of Schirmacher Hills by Banaras Hindu University (BHU), which recorded over 30 species of algae predominantly belonging to cyanobacteria (Pandey and Kashyap, 1998).

Ghosh et al. (1997b), estimated the Shannon weaver diversity index values of the phytoplankton present in various lakes around Maitri station, which varied between zero and 2.54 indicating poor productivity and, less number and uneven distribution of the species. Zub Lake represented, rotiferans, cladocerans and copepodids, the lakes at western side of Maitri station, contained only one species of nematode. Altogether eight varieties of zooplankton were recorded in surface water samples Diversity index values varying from nil to 1.37 for zooplankton indicate nonproductive water bodies.

The bacterial population in some brackish water lakes of Larsemann Hills was enumerated by Krishnan et al. (2009), shows that both freshwater and saline bacteria were encountered in the lakes. These lakes were also found to harbor a large number of manganese oxidizing bacteria, predominantly belonging to the genera Shewanella, Pseudomonas and an unclassified genus in the family Oxalobacteriaceae. During the XXVIII to XXX-ISEA, bacterial population in some lakes of Larsemann Hills was enumerated. No pathogenic population such as Coliform, Salmonella, Staphylococcus and Psedomonas was encountered (Khandal et al., 2010). However, during XXXIII-ISEA (2013-14), water sample collected from lakes of Schirmacher and Larsemann Hills as well as from the seashore near Bharati station, processed to isolate 208 bacteria which includes; psychrophiles, heterotrophs and pathogens. Few lakes at Broknes shown presence of suspected E.Coli; Enterobacter, Shalmonela, Shigella, and Staphylococcus species (personnel communication, unpublished data by $\mathrm{S}$ Kerkar).

\section{Alien Species: Threat to Ecosystem}

The rapid global warming can affect an ecosystem changes to adopt naturally. Pollution of water of ponds, lakes and Oceans is increasing day to day which threatened the future course of life. The invasion of native ecosystems by non-native or alien organisms; weeds, pathogens, predators, etc., is now widely regarded as a top threat to biological diversity worldwide. Of the many non-native species that may be introduced to a native ecosystem, some act as competitors, predators, pathogens, or disrupters of key ecological processes (nutrient cycling, flood or fire regimes, etc.). Others exhibit no clear negative impacts, or may enhance the habitat for certain native species while harming other native components. Invasive species are described as "critical", "widespread", or "among the top" sources of stress to conservation targets. Thus there is urgent need of conservation to find ways of maintaining the high levels of biological diversity that are seen in today's world. The synonymous terms was used to describe aliens species are: introduced, exotics, non-natives. The, "invasive alien" has been widely used since the $20^{\text {th }}$ century (McGeoch et al., 2015; Tiwari et al., 2006; Walton, 1987). SCAR and ATCM have developed various guidelines and recommended measures to be adopted in order to avoid introduction of alien species in Antarctica (WP-25, 2012; WP-53, 2011). Logistic operation including cargo, ship, aircraft and transport vehicle, may act as carrier to invasive alien species if proper measures are not adopted. Detailed study on identification of alien species at Indian stations is to be initiated soon. 


\section{Initial Environmental Evaluation (IEE)}

Activities to be undertaken (Scientific and Logistics) in Antarctica Treaty area should be assessed for less than minor, minor or transitory and more than minor or transitory according to Article 8 of Environmental Protocol. Assessment procedure as mentioned in Annex-1 of Protocol should be followed (ATS, 2002). Lamers et al. (2014) also in opinion that experiences in the use of strategic thinking and strategic environmental assessment tools in and outside of Antarctica represent exemplars that can be adopted by stakeholders in an Antarctic setting and can be scaled up to the Antarctic region as a whole. A more strategic approach to environmental governance in Antarctica should consist of different components, including strategic thinking, planning, decision making, implementation and monitoring.

Proposed activities at Maitri and Bharati station have been carefully examined to prepare IEE for placement of shelter hut (IP-002, 2007), installation of earth station (IP-026, 2008), wind energy generators (IP-021, 2009; IP-049, 2008), approach path (IP-001, 2010) and ground station (IP-075, 2013). Preparation of IEE is useful tool to adopt environmental measures during project implementation.

\section{Environmental Impact Assessment}

Research undertaken in Antarctica mainly focused on chemical fingerprinting, elucidation of biogeochemical process and pathways, ecological assessment and remediation research, though they are process-oriented (Tin et al., 2009) Human activity attributes to chemical contamination through exhaust gases and fuel spills which is noticeable among other sources (Bargagli, 2008) .

According to the Monitoring of Environmental Impacts from Science and Operations in Antarctica (Bonner and Angel, 1987) the monitoring improvement is to be carried out and implemented which is the intact part of the Post- Environmental Impact Assessment study. Environmental Impact assessment study initiated at Maitri station during austral summer of XIX-ISEA in year 1999-2000, selecting indicators for ambient air (SPM, $\mathrm{SO}_{2}$ and $\mathrm{NO}_{\mathrm{x}}$ ). Essential physico-chemical parameters for analysis of water and wastewater defined and then analysed including biological study of phytoplankton and zooplankton in lake water. Ambient noise levels were monitored on the basis of day-night (Leq) as well as machine noise levels. Soil samples were also collected to assess the particle size distribution, bulk density, water holding capacity, porosity, calcium, sodium, potassium, magnesium, oil and grease and hydrocarbons contamination in the soil.

Air quality prediction carried out employing air quality model, Industrial Source Complex Short Term Version-3 (ISCST-3) for Bharati (Tiwari et al., 2007) and Maitri station and mixing height is calculated based on the radiosonde dada available from the nearby Russian station, Novolazevskaya. Depth of Zub Lake (source of drinking water), which is also known as Priyadarshini Lake, was measured at various places and depth area relationship is obtained to find out the total quantity of water available and also the during summer the total quantity of water melted and stored in Zub lake is also measured form day to day basis of height increment and surface area relationship. An environmental management plan was prepared to mitigate the adverse impact including health and safety of the occupants (Tiwari and Kulkarni, 2004; Tiwari et al., 2006).

\section{Waste Management}

Station has the systems to collect and segregate the waste as per nature of the waste i.e. bio degradable and non-biodegradable. Further, biodegradable waste is also segregated as papers, rags and food waste. Paper rags etc., are burnt in a closed room by incinerator and ash is collected in the drums similarly the human excreta is incinerated and the ash are collected into the drum and all the solid waste is removed from the Antarctica and bring to country for safe disposal. During 1996-97, comprehensive environmental cleaning put into force and around 20 metric ton of waste removed from in and around Maitri station (Ravindra, 2000). Similar exercise carried out in year 2013-14 and 15 ton of waste has been removed which included used oil barrels, vehicle parts, etc.

\section{Conclusion}

Research undertaken in Antarctica mainly focused on chemical fingerprinting, elucidation of biogeochemical process and pathways, ecological assessment and remediation research, though they 
are process-oriented (Acosta-Martínez et al., 2015; Formenti et al., 2011). Holistic environmental monitoring programme at the Indian scientific permanent station, Maitri was started in year 1988. Awareness in environmental monitoring programme has resulted into generation of noticeable database for future comparison. Indian team members are worked also in close cooperation with other country, i.e. Peru, Germany, Iran, France, Russia and South Africa.

Black carbon concentration at Maitri and Bharati stations varied in range of $13 \pm 16.2 \mathrm{ng} / \mathrm{m}^{3}$ to $26.5 \pm 16.2$ $\mathrm{ng} / \mathrm{m}^{3}$ is being attributed by long range transport, however local anthropogenic activities are also contributing nearly $1-3 \mu \mathrm{g} / \mathrm{m}^{3}$ of $\mathrm{PM}_{2.5}$. Station operation and maintenance require huge amount of fossil fuel to operate various life supporting machineries and transport vehicles. Generators, incinerators and boilers being operated in stations are the main source of emission to attribute in environment, which may have noticeable impact on the surrounding environment as well as changing albedo of snow cover enriching it with carbon particles (Weller et al., 2013). Fossil fuel burning is main source of $\mathrm{NOx}$ and $\mathrm{SO}_{2}$ emission, though maximum-average ambient concentration of NOx has been recorded in nearly $0.14 \mathrm{ppb}$ at Maitri station, installation of state-of-theart silent generators based on Combined Heat and Power (CHP) concept would mitigate further environmental impact (Fumo et al., 2011; Tiwari et $a l .$, 2007). Presence of mercury is largely attributed to long-range transport, however abrupt change in the concentration of the mercury soon after blizzard is a particular phenomenon that has to be further explored through experiments and observations.

Consumption of water from the lakes for routine need and drinking purpose ultimately produces wastewater and treated effluent also accumulate in the environment or joins water cycle thus enriching soil and sediment with heavy metals, organic and inorganic constituents. Low treatment efficacy of RBC (recorded less than 50\% of BOD and COD removal) is a matter of concern and seepage from wastewater has potential to contaminate downstream lake water, thus in few location concentration of $\mathrm{NO}_{3}$, $\mathrm{PO}_{4}, \mathrm{Cl}$ and $\mathrm{Na}$ have been recorded higher in $\mathrm{Zub}$ lake, then natural concentrations of similar elements, recorded in other lakes at Schirmacher Hills. The analysis of data do not shows the significant change in environmental indicator (heavy metal) except the increment of iron in drinking water and presence of biological indicator, which is attributed to use of old iron pipe and seepage of treated wastewater in Zub lake during summer. Presence of E-Coli and pathogens in nearby lakes of stations indicates careful examination of anthropogenic activities, however birds also acts as vector to transport organic ingredient and dropping into lake water, which may also have been attributed presence of pathogens in lake water (Barbosa and Palacios, 2009; Grimaldi et al., 2014).

Realizing the environmental issues projected through environmental indicators the efficiency of biodisc is improved and new advanced wastewater treatment system with UV filtration has been commissioned. Measures are taken to block the seepage treated water by layering the pond with reinforced polypropylene liner.

Every year around 80-100 scientists/logistics personel reach to Antarctica to stay and work in Indian Antarctic stations. There may be risk of introduction of invasive alien species in the area where they work and stay. However this threat from Antarctica to India is almost not possible due to difference in climatic conditions and survival of microorganisms. Array of measures are required to be implemented at Indian Antarctic stations as well as other stations which do exists in Antarctica. These comprises, year-round environmental monitoring, targeted scientific research, measures on non-native species as well as regulations on non-scientific activities including tourism. Environmental impact due to some human activity are irreversible and it is matter of research and monitoring to distinguish between natural and anthropogenic pollution attributed by local or long range source. ATCM, CEP and COMNAP are further updating guideline on environmental monitoring with inclusion of recent measures, resolution and decisions adopted during recent ATCMs. Stringent measures and standards will improve the present scenario of stations and activities to protect pristine Antarctic environment.

\section{Acknowledgements}

The author would like to thank Dr Shailesh Nayak, distinguish Scientist at Ministry of Earth Sciences and Chair of Indian National Committee for SCAR (former 
Secretary to Ministry of Earth Sciences, Government of India), for providing opportunity to develop the manuscript. This paper is part of environmental monitoring carried out by Bhabha Atomic Research Centre (Mumbai), CSIR-National Environmental Engineering Research Institute (Nagpur), Shriram Institute of Industrial Research (New Delhi), Indian Institute of Technology (Mumbai and Hyderabad), Goa University (Goa), Amity University (Noida) and ESSO-National Centre for Antarctic and Ocean

\section{References}

Acosta-Martínez V, Van Pelt S, Moore-Kucera J, Baddock M C and Zobeck T M (2015) Microbiology of wind-eroded sediments: Current knowledge and future research directions Aeolian Research 18 99-113. doi:10.1016/ j.aeolia.2015.06.001

Alam S I, Dube S, Reddy G S N, Bhattacharya B K, Shivaji S and Singh L (2005) Purification and characterisation of extracellular protease produced by Clostridium sp. from Schirmacher oasis, Antarctica Enzyme and Microbial Technology 36 824-831 doi: http://dx.doi.org/10.1016/ j.enzmictec.2005.01.011

Alam S I, Singh L, Dube S, Reddy G S and Shivaji S (2003) Psychrophilic Planococcus maitriensis sp.nov. from Antarctica Syst Appl Microbiol 26 505-510 doi: 10.1078/ 072320203770865792

Anonymous (1981) The atmospheric aerosol. In: Meszáros E (ed) Studies in Environmental Science 11 Elsevier, pp 91132 doi:_http://dx.doi.org/10.1016/S0166-1116(08)707659

ATS (2002) Handbook of Antarctic Treaty System. Ninth edn. Department of State, United States

Babisch W, Houthuijs D, Pershagen G, Cadum E, Katsouyanni K, Velonakis M, Dudley M-L, Marohn H-D, Swart W, Breugelmans O, Bluhm G, Selander J, Vigna-Taglianti F, Pisani S, Haralabidis A, Dimakopoulou K, Zachos I and Järup L (2009) Annoyance due to aircraft noise has increased over the years-Results of the HYENA study Environment International 35 1169-1176 doi: http:// dx.doi.org/10.1016/j.envint.2009.07.012

Baldauf R, Thoma E, Khlystov A, Isakov V, Bowker G, Long T and Snow R (2008) Impacts of noise barriers on near-road air quality Atmospheric Environment $427502-7507$ doi: http://dx.doi.org/10.1016/j.atmosenv.2008.05.051
Research (Goa), so these institutes as well as concerned scientists are gratefully acknowledged for providing report and information, although views expressed herein may not of those concerned. Author would like also to thank Dr M. Ravichandran, Director, ESSO-NCAOR for providing his consent to publish this manuscript.

This paper has been sumbitted under ESSONCAOR contribution number 39/2016.

Barbosa A and Palacios M J (2009) Health of Antarctic birds: a review of their parasites, pathogens and diseases Polar Biology 321095 doi:10.1007/s00300-009-0640-3

Bargagli R (2008) Environmental contamination in Antarctic ecosystems Science of the Total Environment $400212-226$ doi: http://dx.doi.org/10.1016/j.scitotenv.2008.06.062

Bera S K, Phartiyal B and Sharma A (2012) An Evidence of Pollen - Spores Retrieved from Lichen Patches Distributed in Schirmacher Oasis and Adjacent Nunataks, East Antarctica: a Case Study of Pollen Transport Over Polar Region International Journal of Earth Sciences \& Engineering 5 724-735

Blanchette R A, Held B W, Jurgens J A, Aislabie J, Duncan S and Farrell R L (2004) Environmental pollutants from the Scott and Shackleton expeditions during the Heroic Age of Antarctic exploration Polar Record 40 143-151 doi: $10.1017 / \mathrm{s} 0032247403003334$

Bonner W N and Angel M V (1987) Conservation and the Antarctic environment: The working group reports of the joint IUCN/ SCAR Symposium on the scientific requirements for Antarctic conservation Environment International 13 137144

Brooks S, Arimoto R, Lindberg S and Southworth G (2008) Antarctic polar plateau snow surface conversion of deposited oxidized mercury to gaseous elemental mercury with fractional long-term burial Atmospheric Environment 42 2877-2884 doi: http://dx.doi.org/10.1016/j.atmosenv. 2007.05.029

Budhavant K, Safai P D and Rao P S P (2015) Sources and elemental composition of summer aerosols in the Larsemann Hills (Antarctica) Environmental Science and Pollution Research 22 2041-2050 doi: 10.1007/s11356014-3452-0

Buettner K J K (1962) Human aspects of bioclimatological classification. In: Tromp S W (ed) Biometeorology. 
Pergamon, pp 128-140. doi:_http://dx.doi.org/10.1016/ B978-0-08-009683-4.50026-7

Chaubey J P, Moorthy K K, Babu S S, Nair V S and Tiwari A (2010) Black carbon aerosols over coastal Antarctica and its scavenging by snow during the Southern Hemispheric summer Journal of Geophysical Research 115 doi: 10.1029/ 2009jd013381

Clarke A and Harris C M (2003) Polar marine ecosystems: Major threats and future change Environmental Conservation 30 1-25 doi: 10.1017/S0376892903000018

Clarke A D (1988) Aerosol physical chemistry in remote marine regions Journal of Aerosol Science 19 1195-1198 doi: http:/ /dx.doi.org/10.1016/0021-8502(88)90134-6

COMNAP (2005) Practical Guidelines for Developing and Designing Environmental Monitoring Programmes in Antarctica. Antarctic Environmental Officers Network (AEON)

Connor M A (2008) Wastewater treatment in Antarctica Polar Record 44 doi: 10.1017/s003224740700719x

Cossa D, Heimbürger LE, Lannuzel D, Rintoul S R, Butler E C V, Bowie A R, Averty B, Watson R J and Remenyi T (2011) Mercury in the Southern Ocean Geochimica Et Cosmochimica Acta 75 4037-4052 doi: 10.1016/ j.gca.2011.05.001

Douglas O and Murphy E (2016) Source-based subjective responses to sleep disturbance from transportation noise Environment International 92-93 450-456 doi: http:// dx.doi.org/10.1016/j.envint.2016.04.030

Formenti P, Schütz L, Balkanski Y, Desboeufs K, Ebert M, Kandler K, Petzold A, Scheuvens D, Weinbruch S and Zhang D (2011) Recent progress in understanding physical and chemical properties of African and Asian mineral dust Atmospheric Chemistry and Physics 11 8231-8256 doi 10.5194/acp-11-8231-2011

Fumo N, Mago P J and Jacobs K (2011) Design considerations for combined cooling, heating, and power systems at altitude Energy Conversion and Management 52 14591469 doi: http://dx.doi.org/10.1016/j.enconman.2010. 10.009

Gerson N C (1958) From Polar Years to Igy. In: Landsberg H E and Mieghem J V (eds) Advances in Geophysics 5 Elsevier, pp 1-52. doi:http://dx.doi.org/10.1016/S00652687(08)60074-6

Ghosh T K, Muley R D, Ghode R and Ramteke D S (1997a) Water and Wastewater Management at Indian Station Maitri in Antarctica. In: Technical Publication No 11, Scientific Report, Thirteenth Indian Expedition to
Antarctica, Department of Ocean Development, New Delhi. pp 301-311

Ghosh T K and Ramteke D S (1997a) Environmental Status at Maitri, Indian Permanent Station in Antarctica : Preliminary Studies. In: Technical Publication No 11, Scientific Report, Thirteenth Indian Expedition to Antarctica, Department of Ocean Development, New Delhi, pp 267-280

Ghosh T K, Salgonkar L N and Kotangale J P (1997b) Biotic Features of Selective Surface Water Bodies around Indian Station Maitri in Schirmacher Oasis, Antarctica. In: Technical Publication No 11, Scientific Report, Thirteenth Indian Expedition to Antarctica, Department of Ocean Development, New Delhi, pp 294-303

Grimaldi W W, Seddon P J, Lyver P O B, Nakagawa S and Tompkins D M (2014) Infectious diseases of Antarctic penguins: current status and future threats Polar Biology 38 591-606 doi: 10.1007/s00300-014-1632-5

Grobbelaar J U (1974) Primary production in freshwater bodies of the sub-Antarctic island Marion S Afr J Antarctic Res 4 40-45

Harris C M and Meadows J (1992) Environmental management in Antarctica Instruments and institutions Marine Pollution Bulletin 25 239-249 doi: http://dx.doi.org/10.1016/0025326X(92)90676-W

Hiras D N, Manariotis I D and Grigoropoulos S G (2004) Organic and nitrogen removal in a two-stage rotating biological contactor treating municipal wastewater Bioresour Technol 93 91-98 doi: 10.1016/j.biortech.2003.06.005

IP-001 (2010) Initial Environmental Evaluation for Development of Approach Path at Proposed New Indian Research Station at Larsemann Hills, East Antarctica. India, ATCMXXXIII, Urguay

IP-002 (2007) Initial Environmental Evaluation for Placement of Shelter Huts at the proposed site of new Indian Research Base, Larsemann Hills, East Antarctica. India, ATCM XXX, India

IP-021 (2009) Initial Environmental Evaluation for Installation of Wind Energy Generators (WEG) at Proposed New Indian Research Base at Larsemann Hills, East Antarctica. India, ATCM-XXXII, USA

IP-026 (2008) Initial Environmental Evaluation for Installation of Earth Station at Maitri, Schirmacher Oasis, Antarctica. India, ATCM-XXXI, Ukraine

IP-049 (2008) Initial Environmental Evaluation for Installation of Wind Energy Generators (WEG) at Maitri, Schirmacher Oasis, Antarctica. India, ATCM-XXXI, Ukaraine 
IP-075 (2013) Initial Environmental Evaluation for Establishment of the Ground Station for Earth Observation Satellites at the Indian Research Station Bharati at Larsemann Hills, East Antarctica. India, ATCM-XXXVI, Belgium

Kallenborn R, Hung H and Brorström-Lundén E (2015) Chapter 13 - Atmospheric Long-Range Transport of Persistent Organic Pollutants (POPs) into Polar Regions. In: Eddy Y--Z (ed) Comprehensive Analytical Chemistry, vol Volume 67. Elsevier, pp 411-432. doi: http://dx.doi.org/10.1016/ B978-0-444-63299-9.00013-2

Kennicutt Ii M C (1990) Oil spillage in Antarctica Environmental Science and Technology 24 620-624

Khandal R K, Verma V K, Niyogi U K, R K S, Sharma B, Pal N, Kumar M and P K (2010) Longterm Environmental Monitoring and Impact Assessment Stidies at New (Upcoming) Indian Scientific Base, at Larsemann Hills (East Antarctica). Shriram Institte of Industral Research, New Delhi

Kok O B and Grobbelaar J U (1978) Observations on the crustaceous zooplankton in some freshwater bodies of the sub-antarctic island marion Hydrobiologia 59 3-8

Kondratyev K Y, Ivanov V A, Pozdnyakov D V and Prokofyev M A (1986) Natural and Anthropogenic Aerosols: A Comparative Analysis. In: Marini-Bettòlo G B (ed) Studies in Environmental Science, vol Volume 26. Elsevier, pp 281-303 doi: http://dx.doi.org/10.1016/S01661116(08)71801-6

Krishnan K P, Sinha R K, Krishna K, Nair S and Singh S M (2009) Microbially Mediated Redox Transformations of Mangnese (II) along with Some Other Trace elements: A Study from Antarctic Lakes Polar Biology 321765-1778

Kumar P, Shokri M R and Mehrotra I (2002) Water Quality: Lakes of Schirmarcher Oasis, Antarctica. In: Technical Publication No.16, Eighteenth Indian Expedition to Antarctica, Scientific Report, Department of Ocean Development, New Delhi, pp 272-292

Lamers M, Liggett D and Tin T (2014) Strategic thinking for the antarctic environment: The use of assessment tools in governance. In: Antarctic Futures: Human Engagement with the Antarctic Environment. Springer Netherlands, pp 307-327. doi:10.1007/978-94-007-6582-5_14

Leopold L B, Clarke F E, Henshaw B B and Balsley J R (1971) A Procedure for Evaluating Environmental Impact. Circular, US Geological Survey, vol 645

Lokabharathi P A and Krishnakumari L (1997) UV Radiation and Primary Production in the Antarctic waters. In: Scientific Report on Thirteenth Indian Expedition to Antarctica, Technical Publication No. 11. Department of Ocean
Development, New Delhi, pp 323-324

Lyons W B, Welch K A and Bonzongo J C (1999) Mercury in aquatic systems in Antarctica Geophysical Research Letters 26 2235-2238

McGeoch M A, Shaw J D, Terauds A, Lee J E and Chown S L (2015) Monitoring biological invasion across the broader Antarctic: A baseline and indicator framework Global Environmental Change 32 108-125 doi: http://dx.doi.org/ 10.1016/j.gloenvcha.2014.12.012

Murphy E, King E A and Rice H J (2009) Estimating human exposure to transport noise in central Dublin, Ireland Environment International 35 298-302 doi: http:// dx.doi.org/10.1016/j.envint.2008.07.026

Pande A S (2015) Satellite and Ground based Monitoring of Air Quality at Indian Antarctic Base "Maitri” and Two Indian Cities. M.Tech.Dissertation, Centre for Environmental Science and Engineering, Indian Institute of Technology, Mumbai

Pandey K D and Kashyap A K (1995) Diversiy of Algal Flora in Six Freshwater Streams of Schrimacher Oasis, Antarctica. In: Scientific report on Tenth Indian Expedition to Antarctica, Technical Publication No 8, Department of Ocean Development, New Delhi. pp 219-230

Parker B C and Vince Howard R (1977) The first environmental impact monitoring and assessment in Antarctica. The dry valley drilling project Biological Conservation 12163 177 doi: http://dx.doi.org/10.1016/0006-3207(77)900143

Pineschi L (2001) Chapter 15 - The duty of prior environmental impact assessment of Antarctic activities under the Madrid Protocol and its implementation in the Italian legal system A2 - Walton, Sergio CaroliPaolo CesconDavid W.H. In: Environmental Contamination in Antarctica. Elsevier Science, Amsterdam, pp 363-380 doi: http://dx.doi.org/ 10.1016/B978-008043199-4/50016-2

Ramachandran T V and Balani M C (1998) Report on the Participation by the Bhabha Atomic Research Centre in the Tenth Indian Expedition to Antarctica. In: Technical Publication No 8, Scientific Report, Tength Indian Expedition to Antarctica, Department of Ocean Development, New Delhi. pp 159-180

Ravindra R (2000) Report of the Environmental Task Force. In: Sixteenth Indian Expendilion to Antarctica, Scientific Report, vol Technical Publication No. 14. Department of Ocean Development, New Delhi, pp 1-36

Ravindra R, Tiwari A K, Achuthankutty C T and Rai K N (2011) Final Comprehensive Environmental Evaluation of New Indian Research Station at Larsemann Hills, East 
Anatrctica, XXXIV-Antarctica Treaty Consultative Meeting,IP-006. Argentina

Sathe AP (1994) Baseline Data on Natural Radioactivit and Metal Concentration in Natural Antarctic Samples. In: Ninth Indian Epedition to Antarctica, Technical Publication No. 6. Department of Ocean Development, New Delhi, pp 251-258

Sengupta R and Qasim S Z (1983) Chemical Studies on the Ice shelf, in a Fresh Water Lake and in a Polynya at Princess Astrid Coast, Dronning Maud Land, Antarctica. In: Scientific Report on First Indian Expedition to Antarctica, Technical Publication No. 1. Department of Ocean Development, New Delhi, pp 62-68

Shivaji S, Rao N S, Saisree L, Sheth V, Reddy G S and Bhargava P M (1989) Isolation and identification of Pseudomonas spp. from Schirmacher Oasis, Antarctica Appl Environ Microbiol 55 767-770

Tin T, Fleming Z L, Hughes K A, Ainley D G, Convey P, Moreno C A, Pfeiffer S, Scott J and Snape I (2009) Impacts of local human activities on the Antarctic environment Antarctic Science 21 3-33 doi: 10.1017/ S0954102009001722

Tiwari A K and Kulkarni S (2004) Environmental Status at Indian Polar Research Station Maitri - A Comprehensive Study. In: A. C (ed) Ninteenth Indian Expedition to Antarctica, Scientific Report, vol Technical Publication No 17. National Centre for Antarctic and Ocean Research through NISCAIR, CSIR, New Delhi, pp 189-221

Tiwari A K, Kulkarni S, Ramteke D S and Nayak G N (2006) Environmental Quality at Maitri Station in Antarctica Journal of Environmental Science and Engineering 48 191198

Tiwari A K and Nayak G N (2007) Water Abundance and Effect of Glacier Melting at Priyadarshini Lake in Antarctica Journal of Institution of Engineers India (Environmental Engineering) 88 27-32

Tiwari A K, Nayak G N and Pandey P C (2009) Wastewater Fate at Maitri in Antarctica Journal of Institution of Engineers India (Environmental Engineering) 90 49-54
Tiwari A K and Qureshi A (2016) Mercury Assessment at Indian Antarctic Stations in Antarctica - A Preliminary Study. In: Society for Environmental Toxicology and Chemistry Asia Pacific, Singapore, Singapore, 2016

Tiwari A K, Ravindra R, Rajan S, Khare N and Saxena A (2007) Draft Comprehensive Environmental Evaluation of New Indian Research Base at Larsemann Hills, Antarctica. XXX Antarctica Treaty Consultative Meeting. New Delhi

Tiwari A K, Singh S M and Pandey P C (2006) Invasive Alien Species : Threat to Antarctic Biodiversity and Control Mechanism. In: Rai L C and Gaur J P (ed) Invasive Alien Species and Biodiversity in India. Gautam Printers, Varanasi, India, pp 160-168

Walton D W H (1987) Antarctic terrestrial ecosystems Environment International 13 83-93 doi: http://dx.doi.org/ 10.1016/0160-4120(87)90046-8

Walton D W H and Morris E M (1990) Science, environment and resources in Antarctica Applied Geography 10 265-286 doi: http://dx.doi.org/10.1016/0143-6228(90)90035-N

Walton D W H and Shears J (1994) The need for environmental monitoring in antarctica: Baselines, environmental impact assessments, accidents and footprints International Journal of Environmental Analytical Chemistry 55 77-90 doi: $10.1080 / 03067319408026210$

Weller R, Minikin A, Petzold A, Wagenbach D and König-Langlo G (2013) Characterization of long-term and seasonal variations of black carbon (BC) concentrations at Neumayer, Antarctica Atmospheric Chemistry and Physics 13 1579-1590 doi: 10.5194/acp-13-1579-2013

Witherow R A and Lyons W B (2008) Mercury deposition in a polar desert ecosystem Environmental Science and Technology 42 4710-4716. doi:10.1021/es800022g

WP-25 (2012) Guidelines to minimise the risks of non-native species and disease associated with Antarctic hydroponics facilities. Australia and France, XXXV-ATCM, Hobart

WP-53 (2011) Measures to reduce the risk of non-native species introductions to the Antarctic region associated with fresh foods. SCAR,XXXIV-ATCM, Buenes Aires. 